Division of Geological \& Geophysical Surveys

PRELIMINARY INTERPRETIVE REPORT 2008-3c

\title{
RECONNAISSANCE INTERPRETATION OF PERMAFROST, ALASKA HIGHWAY CORRIDOR, DELTA JUNCTION TO DOT LAKE, ALASKA
}

\author{
by \\ Richard D. Reger and Diana N. Solie \\ September 2008 \\ THIS REPORT HAS NOT BEEN REVIEWED FOR \\ TECHNICAL CONTENT (EXCEPT AS NOTED IN TEXT) OR FOR \\ CONFORMITY TO THE EDITORIAL STANDARDS OF DGGS. \\ Released by \\ STATE OF ALASKA \\ DEPARTMENT OF NATURAL RESOURCES \\ Division of Geological \& Geophysical Surveys \\ 3354 College Rd. \\ Fairbanks, Alaska 99709-3707
}





\section{CONTENTS}

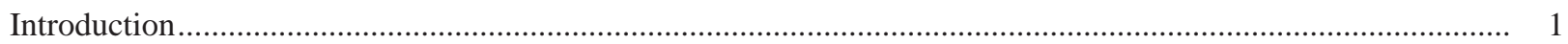

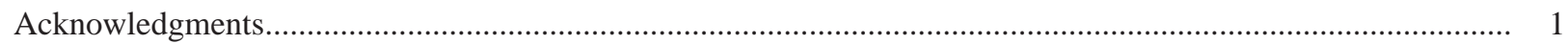

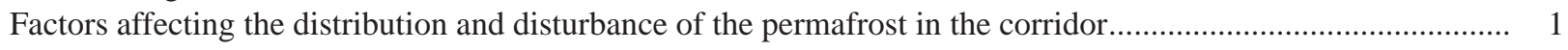

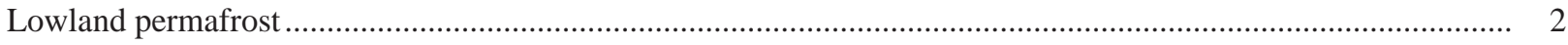

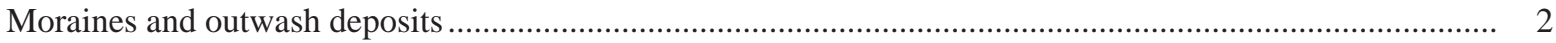

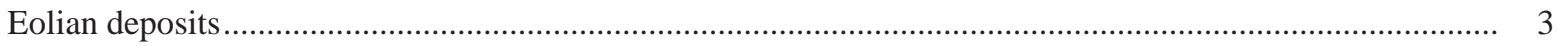

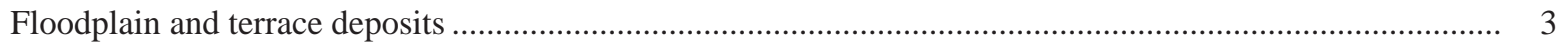

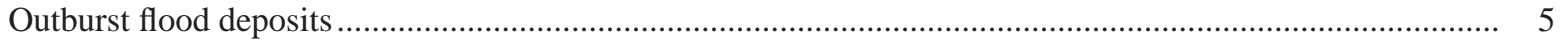

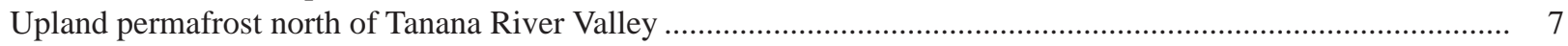

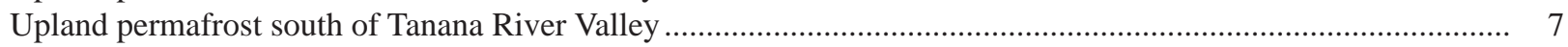

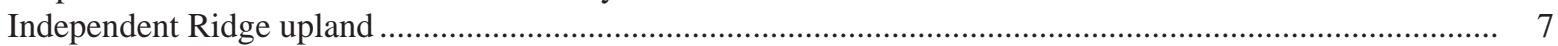

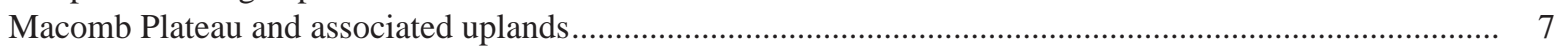

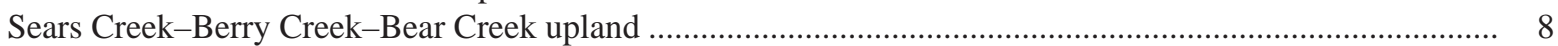

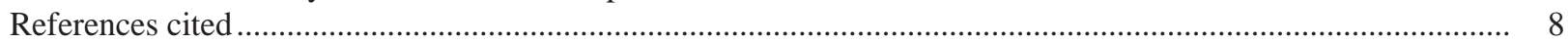

\section{FIGURES}

Figure 1. Evolution of shallow lakes on the floodplains of meandering streams by thermokarst activity

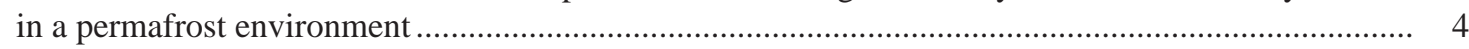

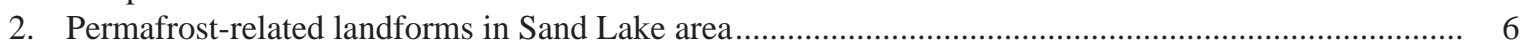

3. Delta-age glacial drift reworked by gelifluction at $\sim 4,350 \mathrm{ft}(\sim 1,325 \mathrm{~m})$ elevation on Macomb Platea.

4. Dense willow and resin birch shrubs with scattered stunted black spruce trees grow on perennially frozen colluvial-alluvial fill in valley bottom, east fork of Berry Creek.

\section{SHEETS}

(in envelope)

Reconnaissance interpretive map of permafrost, Alaska Highway Corridor, Delta Junction to Dot Lake, Alaska 



\title{
RECONNAISSANCE INTERPRETATION OF PERMAFROST IN ALASKA HIGHWAY CORRIDOR, BIG DELTA AND MT. HAYES QUADRANGLES, ALASKA
}

\author{
by \\ Richard D. Reger ${ }^{1}$ and Diana N. Solie ${ }^{2}$
}

\section{INTRODUCTION}

During 2006 and 2007 the Alaska Division of Geological \& Geophysical Surveys (DGGS) conducted reconnaissance interpretive mapping of permafrost in Alaska Highway Corridor Segment 1, a 12-mi (19.3-km) corridor that straddles the Alaska Highway through the Tanana River valley from Delta Junction to the eastern boundary of the Mt. Hayes Quadrangle. Primarily, we inferred the extent of permafrost and ice content by interpreting 1:63,360scale, false-color infrared aerial photographs taken in August 1980. Interpreted proxy data include vegetation, slope and aspect, landforms, geology, local drainage, and terrain features. Landforms such as open-system pingos, polygonal ground, and thermokarst pits, gullies, and ponds are diagnostic of the presence or former presence of permafrost (Hopkins and others, 1955; Ferrians and others, 1969; Kreig and Reger, 1982). In conjunction with the interpretive mapping (sheets 1 and 2), we incorporated information available in the professional literature into the preliminary map. During summer field work in 2007, we dug test pits to verify our initial interpretations. In a supplemental study, Santosh Panda (Geophysical Institute, University of Alaska Fairbanks, Fairbanks, AK) installed Hobo temperature data loggers to evaluate shallow ground temperatures and temperature trends at 14 scattered sites and measured soil moisture contents using an ECH20 moisture sensor (Panda and others, 2008). Initial readings support our interpretation, but, because of a dearth of subsurface data in most of the map area, our permafrost designations should be considered tentative until validated by multi-year ground-temperature measurements below the level of annual temperature variation.

\section{ACKNOWLEDGMENTS}

Most of the background knowledge for this permafrost interpretation was learned during preconstruction geotechnical investigations for the trans-Alaska oil pipeline system (Kreig and Reger, 1976, 1982), and we gratefully acknowledge the vital support and contributions made during those investigations by Alyeska Pipeline Service Company, R \& M Consultants, Inc., and especially Mike Metz and Ray Kreig. We greatly appreciate the logistical support and information provided during our 2007 field work by Steve Squires and members of the Dry Creek community. Santosh Panda accompanied us in the field, was a catalyst for many interesting discussions on relations between vegetation and permafrost, and provided unpublished preliminary information on permafrost in the corridor. Critical support was provided in the field by Gary Carver and by our DGGS colleagues, particularly De Anne Stevens, who has been an invaluable field colleague for many years and graciously agreed to review this report for publication. Her much-appreciated comments greatly improved our report. Funding for this project was provided by the State of Alaska.

\section{FACTORS AFFECTING THE DISTRIBUTION AND DISTURBANCE OF PERMAFROST IN THE CORRIDOR}

Permafrost distribution is a function of present and past climates (Hopkins and others, 1955). As a rough approximation, permafrost forms where the mean annual air temperature is $<0^{\circ} \mathrm{C}$ (Péwé, 1982). To develop perennially frozen ground, the temperature of the ground surface must be $<0^{\circ} \mathrm{C}$ (Ferrians and others, 1969). The most accurate relations between permafrost extent and ground temperatures reflect ground temperatures measured at a depth below the seasonal frost layer where there is no temperature variation (the level of zero annual amplitude of Péwé, 1982, fig. 20). In general, lowland permafrost is continuous (underlies $>90$ percent of the area) where the ground temperature at the depth of no temperature variation varies from $-5^{\circ} \mathrm{C}$ to $-11^{\circ} \mathrm{C}$; permafrost is discontinuous (underlies 50 to 90 percent of the area) where steady ground temperatures are $-1^{\circ} \mathrm{C}$ to $-5^{\circ} \mathrm{C}$ at the level of zero annual change; and permafrost is sporadic (underlies 10 to 50 percent of the area) or is composed of isolated small bodies $\left(<10\right.$ percent of the area) where unvarying ground temperatures are $0^{\circ}$ to $-1^{\circ} \mathrm{C}$ (Ferrians, 1965). In complex mountainous terrains, permafrost temperatures are highly variable.

${ }^{1}$ Reger’s Geologic Consulting, P.O. Box 3326; Soldotna, Alaska 99669

${ }^{2}$ Alaska Division of Geological \& Geophysical Surveys, 3354 College Rd., Fairbanks, Alaska 99709-3707 
Local variations in the volume, depth, thickness, ice content, and temperature of permafrost are the result of differences in heat flow into and out of the ground, which are functions of the local geothermal gradient and interactions of climate and local physiographic and geologic conditions (Williams, 1970). For example, because of low sun angles at the northern latitude of the proposed corridor, the amount of solar radiation reaching the ground surface significantly affects the amount of heat potentially entering the ground. A $10^{\circ}$ south-facing slope receives $\sim 33$ percent more solar radiation than a $10^{\circ}$ north-facing slope and $\sim 14$ percent more solar radiation than a flat surface (Hinzman and others, 2006). Although mean annual air temperatures are generally only $\sim 3^{\circ} \mathrm{C}$ colder in valley bottoms and on north-facing slopes compared to south-facing slopes due to convective atmospheric mixing, ground temperatures are significantly colder on north-facing slopes and valley bottoms because (1) steep winter temperature inversions draw heat out of the ground and (2) during summers there is significant insulation by the surface cover of mosses and lichens, which is widespread on north-facing slopes and valley bottoms. In summer, the moist ground cover dries in the continental climate and insulates permafrost from atmospheric temperature fluctuations, reducing heat flow from the warmer atmosphere into the colder ground. In winter, when this ground cover is frozen, heat flows from the warmer ground into the colder atmosphere. In wet sphagnum bogs, this natural heat pump allows 2.5 to 4.5 times more heat flow out of the ground in winter than heat flow into the ground in summer, promoting the formation and preservation of permafrost in these wetland sites (Kreig and Reger, 1982, plate 5). Thus, topography significantly affects the distribution of permafrost and vegetation, which is a sensitive indicator of ground temperature conditions, especially in the southern Yukon-Tanana Upland.

Near-surface permafrost thaws when ground temperatures rise above $0^{\circ} \mathrm{C}$, as when the thermal properties of the ground surface are altered by human activities, geologic processes like slope failures, or wildfires so that heat flow into the ground exceeds winter heat loss. These changes lower the permafrost table and thicken the active layer of seasonal thawing (Ferrians and others, 1969). Responses to the thawing of perennially frozen ground are functions of the amount and type of ground ice present. Permafrost contains several forms of ground ice, including buried snow, lake ice, aufeis, glacier ice, pingo-ice lenses, foliated ice wedges, regelation and injection ice masses, small segregations of clear ice, and pore ice (French, 2007). Melting of massive ground-ice bodies results in considerable differential settlement of the ground surface and the formation of large thaw ponds, thaw lakes, and thaw basins (alases) (Kreig and Reger, 1982). Melting of foliated ice wedges, which form polygonal cells in permafrost, produces mounds separated by differentially settled polygonal troughs (Péwé, 1954). Melting of permafrost rich in small, segregated ice lenses and thin ice seams produces general lowering of the ground surface without significant differential settling. Thawing of coarse sand and gravel with clear pore fillings may result in no settlement. Pre-burn vegetation typically returns a few years after a wildfire in an area, either directly or through a series of successional stages, depending on the type of vegetation formerly present and the severity of the burn (Chapin and others, 2006), and permafrost may become re-established in soils thawed as a result of the wildfire.

\section{LOWLAND PERMAFROST}

\section{MORAINES AND OUTWASH DEPOSITS}

In Corridor Segment 1 through the upper Tanana River valley from Delta Junction to Dot Lake, where the average annual air temperatures range from $-3.4^{\circ} \mathrm{C}$ at Delta Junction (record taken $1980-2007$ ) to $-4.5^{\circ} \mathrm{C}$ at Dot Lake (record taken 1968-1970) (http://www.wrcc.dri.edu/htmlfiles/ak/ak.tmp.ext.html), permafrost is present as continuous, discontinuous, and isolated bodies. In terminal moraines and associated outwash deposits in the western half of the corridor segment, permafrost exists as deep, isolated, relict masses with low ice content (Péwé, 1955, fig. 9). According to Williams (1970), permafrost at Fort Greely is present in 33 percent of the water wells and is deeper than $217 \mathrm{ft}(66 \mathrm{~m}$ ), and groundwater distribution is controlled by subsurface stratigraphy, not permafrost. Surface manifestations of permafrost are generally lacking on coarse-grained outwash deposits, except for small thaw ponds in thin peaty fillings of local basins and in the blanket of frozen loess west of Delta River. However, small, shallow masses of modern permafrost are reported in coarse outwash alluvium of Donnelly age in the Fort Greely-Delta Junction area (Wilcox, 1980), and trenches along the route of the Trans-Alaska Pipeline System across the late Donnelly outwash fan north of Delta Junction encountered small, active polygonal ice wedges (Alyeska Pipeline Service Company, 1976; Péwé and Reger, 1983). In the Fort Greely-Delta Junction area, abandoned channels of Jarvis Creek that cross the Donnelly outwash fan are seasonally flooded because of aufeis formation in the modern channel of Jarvis Creek. Test pits and soil borings indicate that organic silt fillings in these channels are discontinuously frozen with scattered, isolated crystals of ice. Contraction-crack polygons also form networks 
on the tread of the post-Donnelly terrace along the west side of Delta River (Reger and Péwé, 2002).

Extensive cleared fields between Delta River and Gerstle River probably have degraded discontinuous permafrost. Shrub-vegetated, fine-grained distal deposits of colluvial-alluvial fans emanating from valleys of the Granite Mountain block are pocked with scattered thaw ponds, indicating that frozen fillings likely contain moderate to high amounts of ice.

Delta- and Donnelly-age terminal moraines of Gerstle River and Little Gerstle River (Reger and others, 2008a) are probably discontinuously frozen with low ice contents. In general, Delta moraines have more frequent and larger kettle fillings of slopewash sediments, lowland loess, and peat, which probably contain thin, ice-rich masses of permafrost. Outwash of Donnelly age is discontinuously frozen with low to moderate ice content, depending on the surface cover of lowland silt and the vegetation cover. Williams (1970, p. 43-44) documented permafrost in a water well in Donnelly outwash near Gerstle River (locality A on sheet 1). The well penetrated $122 \mathrm{ft}(37 \mathrm{~m}$ ) of permafrost from the ground surface down through $80 \mathrm{ft}(24 \mathrm{~m})$ of surface outwash gravel and $42 \mathrm{ft}(13 \mathrm{~m})$ of underlying sand and till. Because well yield was inadequate, the well was deepened to $549 \mathrm{ft}(167 \mathrm{~m})$. Eventually, adequate water was obtained from sand and gravel between depths of 468 and $472 \mathrm{ft}$ (143 and $144 \mathrm{~m}$ ). Water level subsequently rose $11 \mathrm{ft}(3.4 \mathrm{~m})$ in the pipe and stabilized $335 \mathrm{ft}(102 \mathrm{~m})$ below the base of the permafrost, indicating that subsurface stratigraphy, not permafrost, controls the distribution of groundwater there.

Permafrost was not encountered in the 140-ft-deep (42-m-deep) water well drilled in September 2001 for the Dry Creek Community in proximal outwash deposits near Johnson River (locality B on sheet 1) (Steve Squires, unpublished data).

\section{EOLIAN DEPOSITS}

In unburned areas on the thick loess blanket west of Delta River, permafrost is sporadic with low ice contents, based on known permafrost conditions in equivalent landforms east of Delta River. Organic silt and sand fillings of thaw basins and small thaw ponds are likely frozen with moderate to high ice contents. Numerous thaw ponds in sandy eolian silt on the broad, coalescent outwash fans of Delta and Donnelly ages east of Delta River indicate that near-surface permafrost is thin and discontinuous with low to moderate ice contents. Based on borings in sand deposits in the Shaw Creek area (Kreig and Reger, 1982, plate 9), mappable sand dune complexes on outwash fans in this first corridor segment probably have low to very low ice contents.

The Donnelly terminal moraine at Johnson River has an extensive and fairly thick cover of eolian sand and silt deposited by strong katabatic winds blowing across the nearby braided floodplain (Reger and others, 2008a). The presence of deciduous and mixed deciduous-coniferous forests on high-relief esker-kame deposits, till, and sand dunes indicates that permafrost is discontinuous with low ice content. Widespread coniferous woodland, primarily black spruce, on surfaces of low relief indicate the presence of discontinuous permafrost with generally low to moderate ice contents. Continuous permafrost with high ice content is probably present in peaty kettle fillings and in local drainage systems with sedge-shrub vegetation.

\section{FLOODPLAIN AND TERRACE DEPOSITS}

Understanding the plant succession on the floodplains of the Tanana River and its relation to developing permafrost conditions is fundamental to our mapping of permafrost in the floodplain and terraces, which is based to a large measure on the character of the surface vegetation. Although the general succession has been known for many years (Viereck, 1970; Kreig and Reger, 1982), the significance of black spruce in the sequence remains uncertain (Mann and others, 1995). The succession begins with the emergence of bare channel bars and meander scrolls on the concave, inner sides of meanders. Scattered willows and horsetails opportunistically colonize the raw mineral soils, which freeze and thaw annually. Within $\sim 5$ years, horsetail meadows and open thickets primarily of willows develop on the inactive floodplain. These communities can accommodate periodic inundation and sediment accumulation by the growth of adventitious roots (Chapin and others, 2006). Then alders and balsam poplars invade older floodplain surfaces, the former adding important nitrogen to the soil through the action of nitrogen-fixing bacteria on their roots. In this phase, permafrost is sporadic and has low ice content. After $~ 50$ years, fast-growing poplars rapidly rise above and replace the willows, which are not shade tolerant, forming poplar groves of generally uniform ages and allowing permafrost to spread and thicken. On older, higher surfaces of the inactive floodplain, white spruce, which has shade-tolerant seedlings that are unable to tolerate frequent burial and do not survive frequent flooding on younger surfaces, is able to survive. Spruce is slower growing than poplars but lives longer, so gradually the spruce mixes with the poplars and replaces them. During this shady phase when the surface cover of mosses and lichens thickens enough to insulate the ground, permafrost becomes discontinuous 


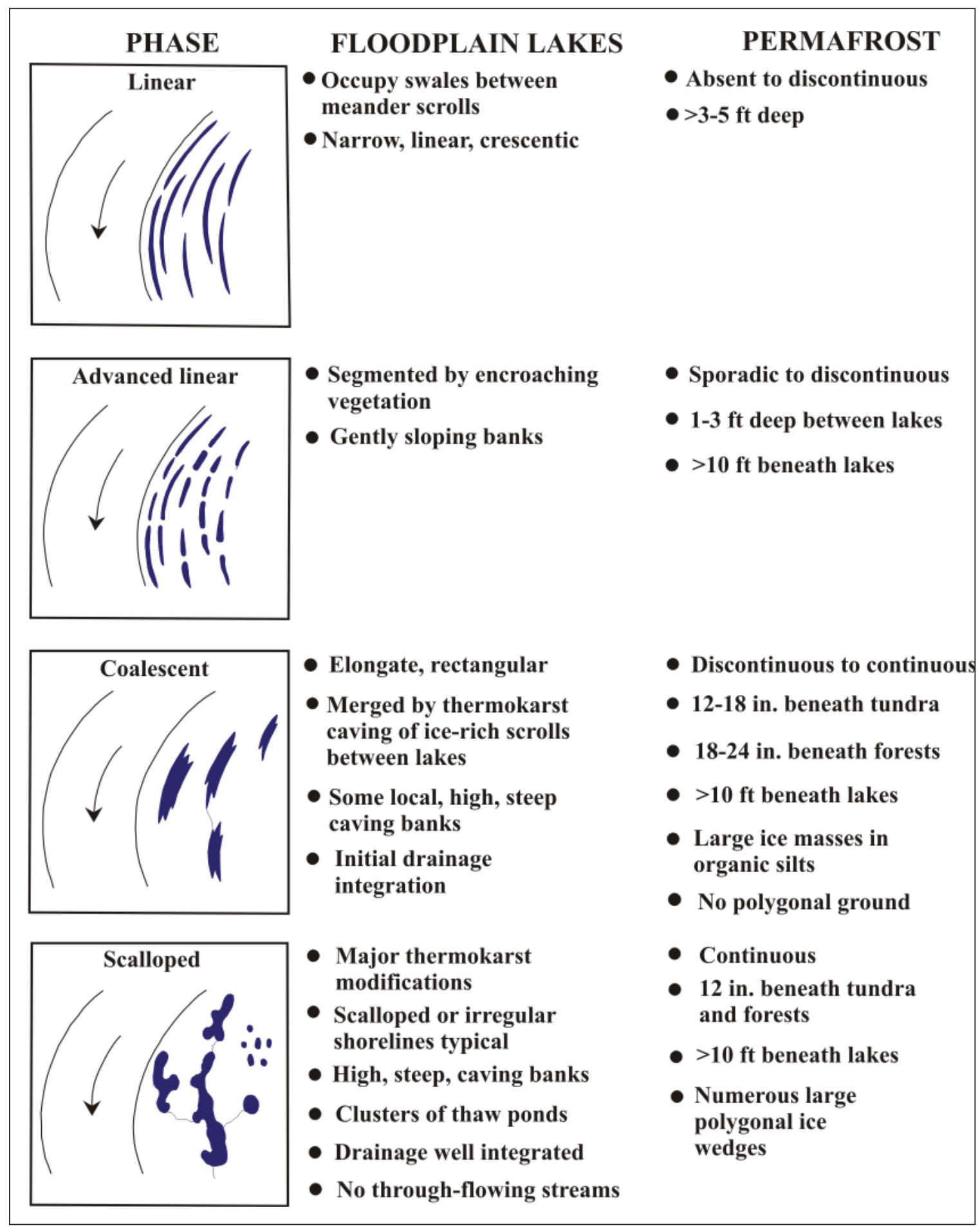

Figure 1. Evolution of shallow lakes on the floodplains of meandering streams by thermokarst activity in a permafrost environment (Péwé, 1970; Weber and Péwé, 1961, 1970). 
and develops low to moderate ice contents. Gradually, forests of mixed white and black spruce develop on the abandoned floodplain, especially on natural levees and crevasse splays, which stand above the surrounding land surface and are better drained. These mixed conifer forests may persist for several millennia (Mann and others, 1995). In lowlands behind natural levees and crevasse splays on the abandoned floodplain, occasional flooding produces moist to wet soil conditions in which black spruce and eastern larch dominate (Viereck, 1970), and peat accumulates, promoting the development of continuous ice-rich permafrost.

Changes in the form of point-bar lakes that develop in swales between low scroll ridges on the floodplains of meandering streams document four successive phases in the development of permafrost (fig. 1). These phases are distinguished on the basis of lake shapes, vegetation, orientation of lakes relative to the modern channel, character of the former river bank, and distribution of driftwood (Péwé, 1975, p. 68). Perennially frozen ground is absent in the linear phase of the inactive floodplain, but discontinuous masses begin forming in the advanced linear phase on older, higher surfaces of the inactive floodplain. Permafrost spreads and thickens beneath the abandoned floodplain and low terraces, causing point-bar lakes to expand and coalesce through the melting of ice-rich frozen ground, and, in the coalescent and scalloped phases, permafrost becomes continuous, shallow, and ice rich.

Floodplain and low terrace deposits in the corridor consist of sand with beds and lenses of silt and gravel where channels are meandering and anastomosing and are composed of gravel and sand in reaches with braided channels (Reger and others, 2008a). The meandering-anastomosing channels of the Tanana River and the active braided floodplains with numerous, unvegetated bars of its major tributaries are generally unfrozen and permafrost does not develop until these surfaces become stabilized and plants become established (Viereck, 1970; Kreig and Reger, 1982). Large floodplain islands that support mature stands of white and black spruce have discontinuous permafrost (Mann and others, 1995), and perennially frozen ground generally has low ice content (Kreig and Reger, 1982). By analogy, post-Donnelly terraces along Tanana River with extensive covers of mature white and black spruce also contain discontinuous permafrost with low ice content. Episodic wildfires on uplands and on post-Donnelly terraces closer to Delta River have burned extensive areas, and permafrost mapping is uncertain.

Permafrost is absent beneath Clearwater Lake and Clearwater Creek, which exist because high-volume, perennial springs emerge along the base of the nearby Clearwater Lake escarpment (Wilcox, 1980). The abandoned floodplain of the Tanana River in the vicinity of Clearwater Lake is vegetated with dense willow thickets and scattered black spruce and eastern larch, indicating that permafrost is discontinuous with low to moderate ice content. Concentrations of small thaw ponds are signs that perennially frozen ground is locally shallow and ice rich. Better drained natural levees and crevasse splays support stands of robust white and black spruce, indicating discontinuous permafrost with low ice content. On interchannel islands on the Holocene fan of lower Sawmill Creek along the southern margin of the abandoned Tanana River floodplain, moist soils support dense stands of black spruce and eastern larch and dense willow thickets, indicating that permafrost is discontinuous with low to moderate ice contents (Viereck and Little, 1972). However, the network of small, braided, peat-filled, anastomosing channels is likely to be generally unfrozen, and, because they are connected with groundwater at depth, water tables are consistently high. These conditions are unusual for the abandoned floodplain of the Tanana River, where perennially frozen ground is usually shallow, continuous, and ice rich (Kreig and Reger, 1982; Mann and others, 1995), and may be related to an influx of relatively warm surface runoff from Sawmill Creek and Rhoads Creek.

In the vicinity of Johnson Slough and in the lowland north of Dot Lake Village, the Tanana River has an anastomosing-meandering pattern that is mimicked by former channels and by floodplain lakes on inactive and abandoned floodplain surfaces and on low terraces (Reger and others, 2008a). The extent of permafrost and its ice content in the Dot Lake lowland are questionable because of the abundance of water, which has promoted widespread growth of peat. This lowland probably is a zone of groundwater emergence, which would introduce considerable heat into the environment and limit permafrost development. Although we generally classify permafrost in abandoned floodplains as continuous and ice rich, we tentatively believe that permafrost in this particular lowland is discontinuous with low to moderate ice content (Dm?).

\section{OUTBURST FLOOD DEPOSITS}

Based on conditions in analogous terraces near Fairbanks (Péwé and others, 1966), gravel and sand expansion fans deposited by massive pre-Holocene flooding in response to failure of glacier dams in the upper Tanana River valley and its tributaries (Reger and others, 2008b) probably contain discontinuous permafrost with low to moderate ice content. Shrubby and sedge-dominated surface vegetation and the presence of numerous open-system pingos and thermokarst features indicate that fine-grained deposits and peat in slackwater basins behind the expansion fans are continuously frozen with moderate to high ice contents (Reger and others, 2008 a). Lakes and large ponds dammed by the expansion fans in re-entrants in the southern Yukon-Tanana Upland are not generally 
underlain by permafrost. However, fine-grained deltas built into Black Lake and Sand Lake by Holocene flooding are likely to be continuously frozen and ice rich. The presence of numerous thaw ponds in the Sand Lake deltas indicates that both deltas are very unstable, thawing, and disintegrating (fig. 2). Discontinuous frozen ground was encountered to depths of 25 to $29 \mathrm{ft}$ (8 to $9 \mathrm{~m}$ ) in possible flood deposits during testing of a potential material site (MS 62-2-068-0) (locality C on sheet 1) by Brazo (1988). In 33 test borings made during April 1987 in the gravelrich longitudinal flood bar near upper Sam Creek (MS 62-2-066-2 and extension) (locality D on sheet 1), Brazo (1988) observed frozen ground below the probable depth of annual freezing ( 8 ft) (2.4 $\mathrm{m})$ in half the borings, and permafrost was $>29 \mathrm{ft}(>9 \mathrm{~m})$ thick in one boring.

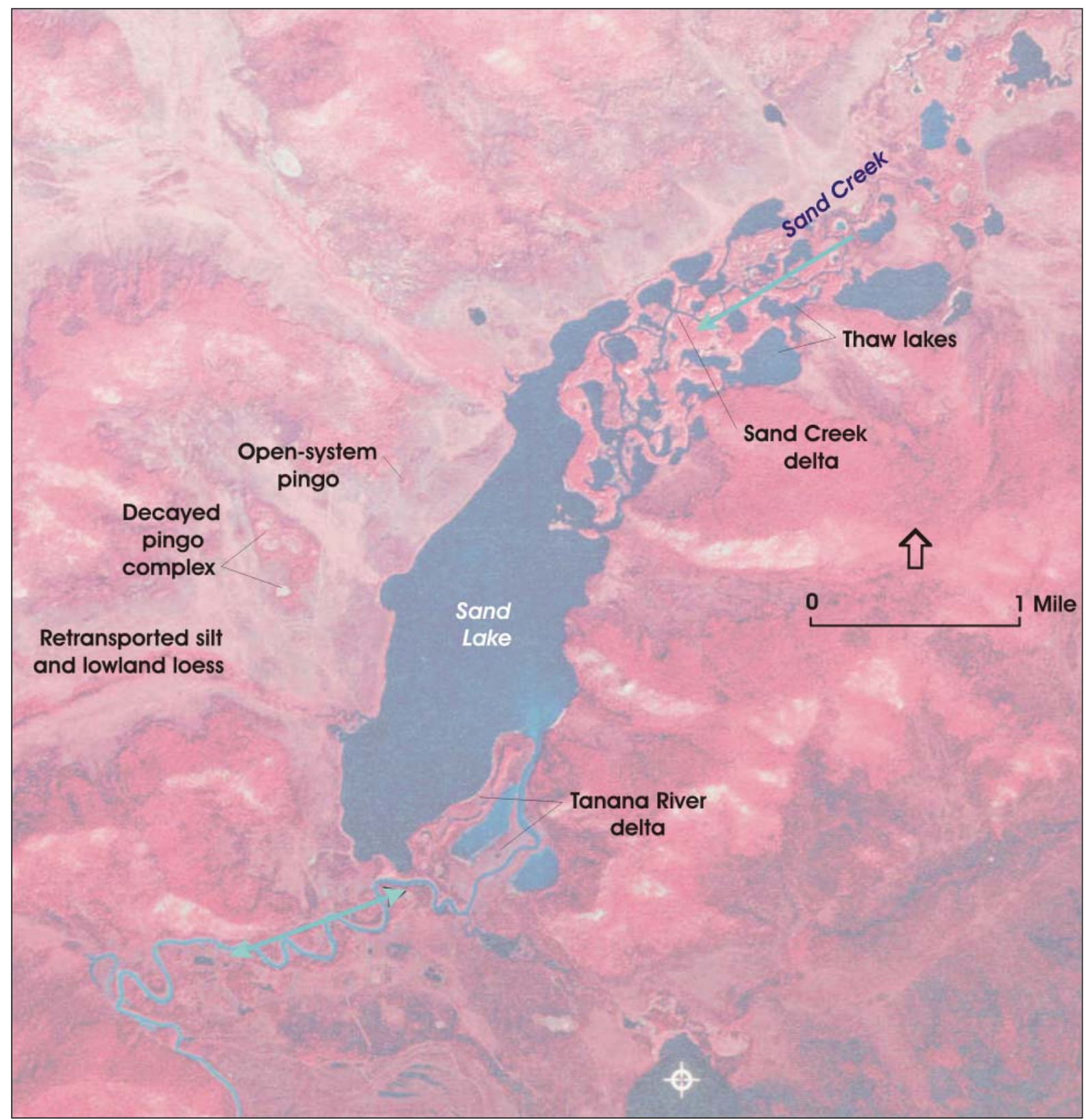

Figure 2. Permafrost-related landforms in Sand Lake area, northcentral Mt. Hayes C-1 Quadrangle, Alaska. Blue arrows indicate directions of stream flows. 


\section{UPLAND PERMAFROST NORTH OF TANANA RIVER VALLEY}

Relatively warm, steep, south-facing bedrock bluffs of the Tanana River along the southern margin of the Yukon-Tanana Upland receive more solar radiation than other slopes and are generally unfrozen. These slopes, which tend to be droughty, support steppe-like vegetation dominated by herbs, shrubs, and scattered aspen and white spruce trees that tolerate aridity (Chapin and others, 2006). Sporadic permafrost with low ice content on upper south-facing slopes and ridge crests is indicated by the forest of deciduous and mixed deciduous-conifer trees. Numerous small areas along ridges in the southern Yukon-Tanana Upland were burned when summer lightning ignited wildfires prior to August 1980. These areas have few trees and are occupied primarily by grasslands with scattered shrubs (Kreig and Reger, 1982, plate 11). In these burn areas, permafrost is mapped as questionable discontinuous with low to moderate ice content, depending on the topographic setting and nearby tree cover. On lower south-facing slopes, permafrost is mapped as discontinuous with low ice content beneath deciduous forest and discontinuous with low to moderate ice content beneath mixed conifer and deciduous forest.

On north-facing slopes, permafrost is likely to be discontinuous with low ice content beneath deciduous forest, discontinuous with low to moderate ice content beneath mixed forest of coniferous and deciduous trees, and continuous with low to moderate ice content beneath black spruce forest. In valley-bottom retransported silt and lowland loess, shallow permafrost is continuous to discontinuous and ice contents probably range from moderate to ice rich. Beneath wet sedge meadows, moist shrublands, and dense black spruce forest, permafrost is almost certainly continuous and ice rich.

Open-system pingos form where intrapermafrost and subpermafrost water under artesian pressure is blocked near enough to the ground surface that hydraulic stress and stresses generated during subsequent ice growth arch the ground upward and allow the water to freeze, forming a lens-shaped ice core (Holmes and others, 1968, fig. 10). These features typically are located on gentle lower slopes and in valley bottoms (sheet 1, fig. 2), where permafrost thickens and becomes continuous but local thawed zones (taliks) allow groundwater movement. Where linear shear zones serve as conduits for groundwater flow through bedrock, pingos are arranged along the shear zones. Many form clusters of slightly different ages, but all are Holocene in age (Holmes and others, 1968). Open-system pingos may be circular, elliptical, or irregular in plan view. During their early growth they form steep-sided, well-drained, tree-covered hills or broad low mounds 50 to $\sim 1,500 \mathrm{ft}$ (15 to $\sim 45 \mathrm{~m}$ ) in diameter and between 10 and $100 \mathrm{ft}$ (3 and $30 \mathrm{~m}$ ) high. Typically, they evolve through a succession of forms. Pingos initially increase in size because of the growth of their lens-shaped ice cores. Eventually, expansion exceeds the tensile strength of the perennially frozen soils above the ice core and the ground fractures at the mound summit, exposing the ice core. Melting of the core follows, causing the summit to subside and, typically, a spring-fed summit pond forms, which conducts heat into the ground and accelerates melting, causing the mound to slowly subside. During this stage, the subsiding rim around the pond may be breached and emerging groundwater may drain away, in some cases totally emptying the summit pond and exposing springs in the basin floor. With further melting and subsidence, the original mound and rim disappear and a thaw basin remains as a round pond or lake.

\section{UPLAND PERMAFROST SOUTH OF TANANA RIVER VALLEY}

\section{INDEPENDENT RIDGE UPLAND}

At elevations between 2,500 and 4,000 ft (758 and 1,333 m) on the western and eastern flanks of northern Independent Ridge, drift of Donnelly age in canyons is probably discontinuously frozen. On south-facing, welldrained, steep bedrock slopes and in upland outcrops, ice contents are probably low to very low, and permafrost is probably near the lower end of the discontinuous range. Permafrost probably has low to moderate ice contents in canyon fills protected from direct solar radiation and beneath upland surfaces that slope gently west, north, and east and have colluvial and residual cover deposits that are sorted and displaced by periglacial processes.

\section{MACOMB PLATEAU AND ASSOCIATED UPLANDS}

Macomb Plateau forms a broad upland surface $\sim 2,800$ to $\sim 3,300 \mathrm{ft}$ ( 848 to $909 \mathrm{~m}$ ) above the floor of the Tanana River valley between Johnson River and upper Berry Creek (sheet 1). Using the air-temperature lapse rate at Northway $\left(-0.81^{\circ} \mathrm{C} / 100 \mathrm{~m}\right)$ (Péwé, 1975 , table 14 ) as a tentative basis, the mean annual temperature on Macomb Plateau is projected to be $\sim 6.8$ to $8^{\circ} \mathrm{C}$ colder than in the nearby Tanana River valley. These climatic conditions and the lack of ice cover on the plateau during the Donnelly glaciation probably produced widespread, shallow permafrost there. The widespread distribution of patterned ground and the efficiency of gelifluction in reworking glacial deposits and frost-rived bedrock to form smooth, gentle slopes, even on slopes as shallow as $1^{\circ}$, implies 


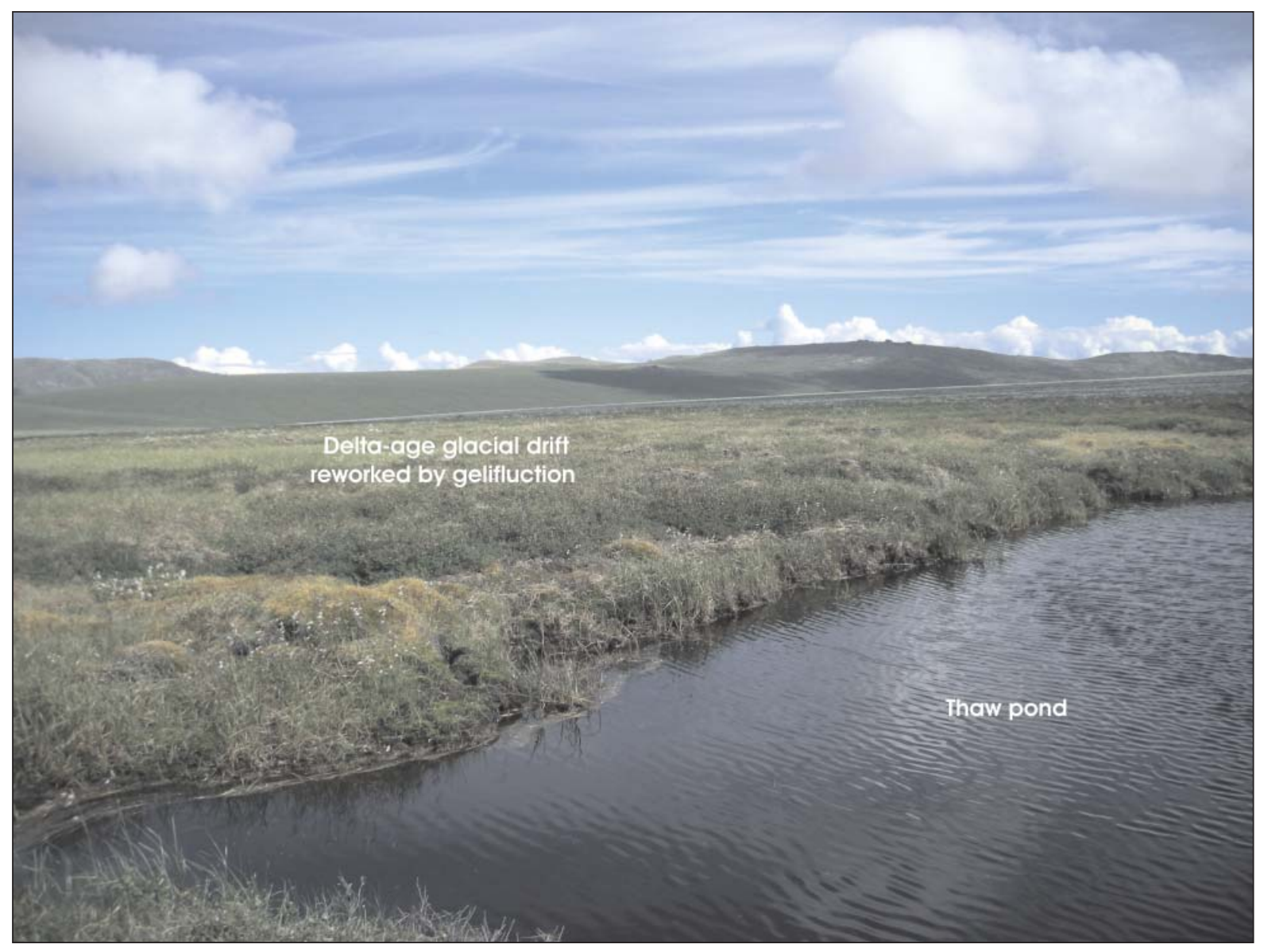

Figure 3. Delta-age glacial drift reworked by gelifluction at 4,350 ft ( 1.325 m) elevation on Macomb Plateau, central Mt. Hayes C-2 Quadrangle, Alaska.

that permafrost is continuous and fairly shallow (fig. 3). Limited observations of the banks of thaw ponds and lakes indicate that the blanket of unconsolidated organic silt with some sand and scattered pebbles, cobbles, and boulders produced by reworking of Delta drift on the plateau is frozen below $1.7 \mathrm{ft}(0.5 \mathrm{~m})$ and locally ice rich to depths of at least $7 \mathrm{ft}(2 \mathrm{~m})$. The presence of small spruce trees submerged in shallow water along the margins of the ponds and fresh sediment exposures indicate that the ponds are expanding. Permafrost is likely discontinuous with low to very low ice contents in bedrock tors, rubble sheets, and steep canyon walls, although foliated and highly fractured rocks may be locally ice rich below the active layer. Colluvial-alluvial fans at the mouths of northern valleys of Macomb Plateau are probably discontinuously frozen with low ice contents, except that shrub and sedge vegetation on fine-grained distal zones indicates that permafrost there is continuous and ice rich.

\section{SEARS CREEK-BERRY CREEK-BEAR CREEK UPLAND}

Fills in tributary valleys are composed of the reworked, sandy, and granule weathering products (grüs) derived from granitic ridges and incorporated organic-rich micaceous silt (lowland loess) (Reger and others, 2008 a). Shrubby vegetation (fig. 4) and the presence of open-system pingos (sheet 1) indicate that permafrost in these unconsolidated deposits ranges from continuous to discontinuous and ice contents range from low to moderate. In test pits dug into organic silts, ice is present as isolated clear crystals. Depth to permafrost is 1.7 to $2 \mathrm{ft}(0.5$ to $0.6 \mathrm{~m})$.

\section{REFERENCES CITED}

Alyeska Pipeline Service Company, 1976, Summary report on investigation and evaluation of Clearwater Lake escarpment near Delta Junction, Alaska: Appendix A-3.1111A, v. 1, 113 p., 5 map sheets, scale 1:63,360. 


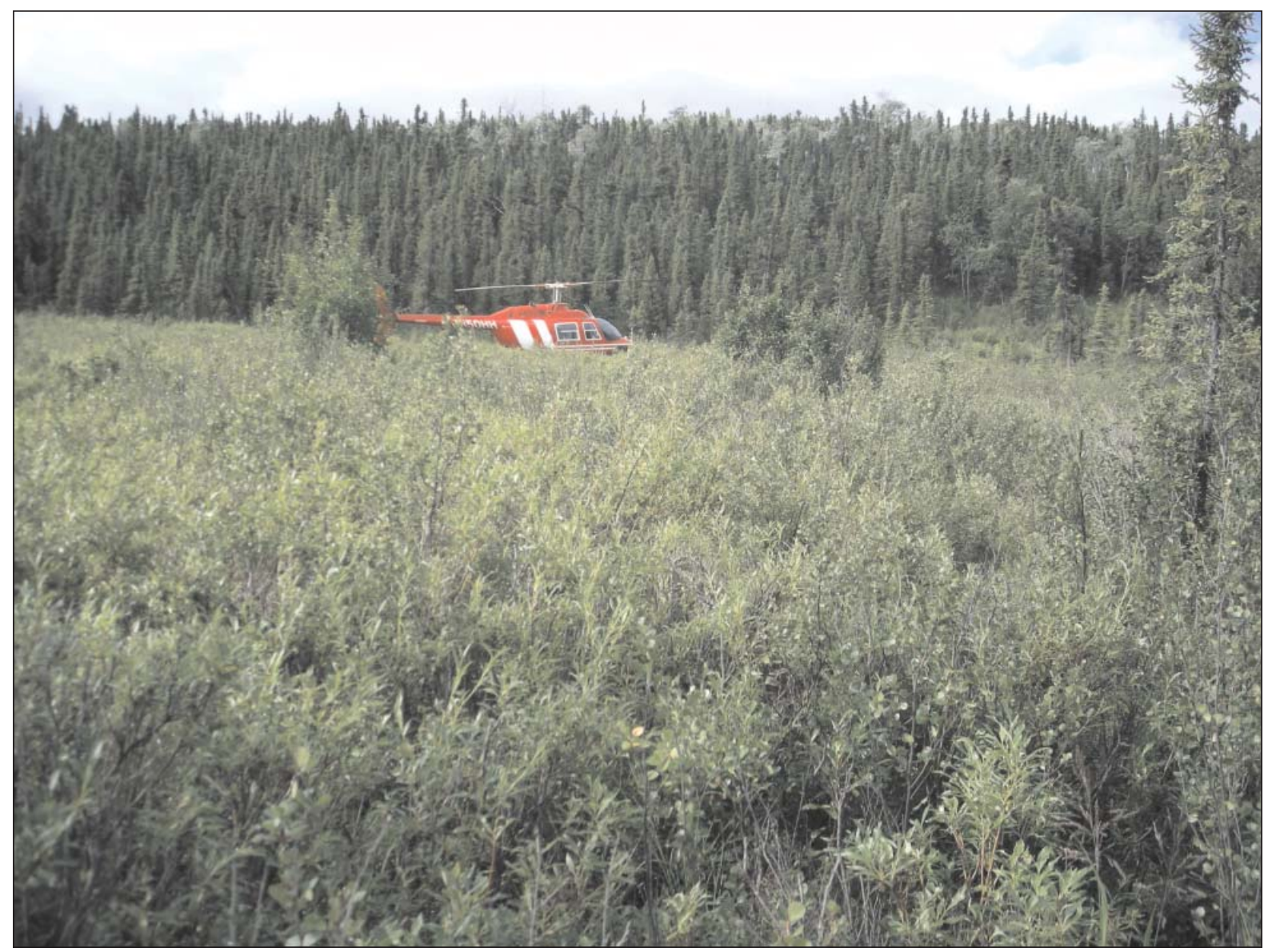

Figure 4. Dense willows and resin birch shrubs with scattered stunted black spruce in foreground grow on perennially frozen colluvial-alluvial fill in valley bottom, east fork of Berry Creek, northwestern Mt. Hayes C-1 Quadrangle, Alaska. Dense black spruce cover south valley wall in background.

Brazo, G.M., 1988, Material site extensions, Supplement 1, Alaska Highway, Johnson River to Dot Lake [Project F-062-2(16)/60229]: Alaska Department of Transportation and Public Facilities Engineering Geology \& Soils report, $24 \mathrm{p}$.

Chapin, F.S., III, Viereck, L.A., Adams, P.C., Van Cleve, Keith, Fastie, C.L., Ott, R.A., Mann, Daniel, and Johnston, J.F., 2006, Successional processes in the Alaskan boreal forest, in Chapin, F.S., III, Oswood, M.W., Van Cleve, Keith, Viereck, L.A., and Verbyla, D., eds., Alaska’s changing boreal forest: Oxford, England, Oxford University Press, p. 100-120.

Ferrians, O.J., Jr., 1965, Permafrost map of Alaska: U.S. Geological Survey Miscellaneous Geologic Investigations Map I-445, 1 map sheet, scale 1:2,500,000.

Ferrians, O.J., Jr., Kachadoorian, Reuben, and Greene, G.W., 1969, Permafrost and related engineering problems in Alaska: U.S. Geological Survey Professional Paper 678, 37 p.

French, H.M., 2007, The periglacial environment: Chichester, England, John Wiley \& Sons, Ltd., 458 p.

Hinzman, L.D., Viereck, L.A., Adams, P.C., Romanovsky, V.E., and Yoshikawa, Kenji, 2006, Climate and permafrost dynamics of the Alaskan boreal forest, in Chapin, F.S., III, Oswood, M.W., Van Cleve, Keith, Viereck, L.A., and Verbyla, D.L., eds., Alaska’s changing boreal forest: Oxford, Oxford University Press, p. 39-61.

Holmes, G.W., Hopkins, D.M., and Foster, H.L., 1968, Pingos in central Alaska: U.S. Geological Survey Bulletin 1241-H, 40 p.

Hopkins, D.M., Karlstrom, T.N.V., Black, R.F., Williams, J.R., Péwé, T.L., Fernald, A.T., and Muller, E.H., 1955, Permafrost and ground water in Alaska: U.S. Geological Survey Professional Paper 264-F, p. 113-146, 15 photo plates. 
Kreig, R.A., and Reger, R.D., 1976, Preconstruction terrain evaluation for the trans-Alaska pipeline project, in Coates, D.R., ed., Geomorphology and engineering: Stroudsburg, Dowden, Hutchinson, and Ross, p. 55-76.

1982, Air-photo analysis and summary of landform soil properties along the route of the Trans-Alaska Pipeline System: Alaska Division of Geological \& Geophysical Surveys Geologic Report 66, 149 p.

Mann, D.H., Fastie, C.L., Rowland, E.L., and Bigelow, N.H., 1995, Spruce succession, disturbance, and geomorphology on the Tanana River floodplain, Alaska: Ecoscience, v. 2, no. 2, p. 184-199.

Muller, S.W., 1947, Permafrost or permanently frozen ground and related engineering problems: Ann Arbor, Michigan, J.W. Edwards, Inc., 231 p.

Panda, S.K., Prakash, A., and Solie, D.N., 2008, Remote sensing-based study of vegetation distribution and its relation to permafrost in and around Lake George area, central Alaska: Ninth International Conference on Permafrost, Fairbanks (accepted), 5 p.

Péwé, T.L., 1954, Effect of permafrost on cultivated fields, Fairbanks area, Alaska: U.S. Geological Survey Bulletin 989-F, p. 315-351.

1955, Middle Tanana Valley, in Hopkins, D.M., Karlstrom, T.N.V., Black, R.F., Williams, J.R., Péwé, T.L., Fernald, A.T., and Muller, E.H., eds., Permafrost and ground water in Alaska: U.S. Geological Survey Professional Paper 264-F, p. 126-130.

1970, Permafrost and vegetation on floodplains of subarctic rivers (Alaska), a summary, in Ecology of the subarctic regions-Proceedings of the Helsinki symposium: UNESCO, p. 141-142.

1975, Quaternary geology of Alaska: U.S. Geological Survey Professional Paper 835, 145 p.

1982, Geologic hazards of the Fairbanks area, Alaska: Alaska Division of Geological \& Geophysical Surveys Special Report 15, 109 p.

Péwé, T.L., and Reger, R.D., 1983, Middle Tanana River valley, in Péwé, T.L., and Reger, R.D., eds., Guidebook to permafrost and Quaternary geology along the Richardson and Glenn Highways between Fairbanks and Anchorage, Alaska: Alaska Division of Geological \& Geophysical Surveys Guidebook 1, p. 5-45.

Péwé, T.L., Wahrhaftig, Clyde, and Weber, Florence, 1966, Geologic map of the Fairbanks Quadrangle, Alaska: U.S. Geological Survey Miscellaneous Geological Investigations Map I-455, 1 map sheet, scale 1:250,000.

Reger, R.D., and Péwé, T.L., 2002, Geologic map of the Big Delta A-4 Quadrangle, Alaska: Alaska Division of Geological \& Geophysical Surveys Report of Investigations 2002-2, scale 1:63,360, 1 map sheet.

Reger, R.D., Stevens, D.S.P., and Solie, D.N., 2008a, Reconnaissance surficial geology map of the Alaska Highway corridor, Big Delta and Mt. Hayes quadrangles, Alaska: Alaska Division of Geological \& Geophysical Surveys Preliminary Interpretive Report 2008-3a, _ _., 2 sheets, scale 1:63,360, in press.

2008b, Evidence of multiple outburst floods, upper Tanana River valley, eastcentral Alaska [abs.]: Geological Society of America Abstracts with Programs, v. 40, no. 1, p. 36.

Viereck, L.A., 1970, Forest succession and soil development adjacent to the Chena River in interior Alaska: Arctic and Alpine Research, v. 2, no. 1, p. 1-26.

Viereck, L.A., and Little, E.L., Jr., 1972, Alaska trees and shrubs: Washington, D.C., U.S. Forest Service Agriculture Handbook 410, 265 p.

Weber, F.R., and Péwé, T.L., 1961, Engineering geology problems in the Yukon-Koyukuk lowland, Alaska, in Short Papers in the Geologic and Hydrologic Sciences 1961: U.S. Geological Survey Professional Paper 424-D, p. 371-373.

1970, Surficial and engineering geology of the central part of the Yukon-Koyukuk lowland, Alaska: U.S. Geological Survey Miscellaneous Geologic Investigations Map I-590, 2 map sheets, scale 1:125,000.

Wilcox, D.E., 1980, Geohydrology of the Delta-Clearwater area, Alaska: U.S. Geological Survey Water-Resources Investigations 80-92, $26 \mathrm{p}$.

Williams, J.R., 1970, Ground water in the permafrost regions of Alaska: U.S. Geological Survey Professional Paper 296, 83 p. 